\title{
Emoções e política: Primeiras aproximações ${ }^{* 1}$
}

\section{Emotions and politics:}

First approximations

\begin{abstract}
CHRISTOPHE PROCHASSON
École des Hautes Études en Sciences Sociales- EHESS, CRH( Centre de Recherche Historique) Boulevard Raspail 105, 75014 - Paris, France Christophe.Prochason@ehess.fr
\end{abstract}

RESUMO Grande parte das pesquisas históricas tem se furtado a abordar do papel das emoções na construção das atividades políticas e sociais; um tipo de estudo a que muitas vezes rechaçam, acusando-o de produzir determinismos psicológicos. Mesmo várias vertentes da História Política fizeram das emoções um objeto estranho às suas discussões, ao optarem pelo estudo exclusivo dos aspectos cognitivos da política, e ao pressuporem serem os sujeitos plenamente conscientes e racionais, orientando-se apenas pelo impulso de satisfazer seus interesses, ou pela fidelidade a suas idéias. Contudo, novas perspectivas historiográficas apontam para a possibilidade de se agregar as dimensões simbólicas e afetivas ao estudo da política. Alinhando-se ao projeto de uma História Social das Emoções Políticas, esse ensaio avalia esses novos procedimentos, centrando-se na abordagem dos sentimentos que teriam regido a adesão política no período moderno, bem como aos repertórios retóricos e expressivos a eles associados. Para tanto, parte-se do exame da expressão das emoções, e seus usos, presentes nos textos de um pen-

Artigo recebido em: 19/10/2004. Autor convidado.

Tradução de René Lommez 
sador que é, ao mesmo tempo, ator e arguto observador do cenário político de sua época: Tocqueville. Fundindo o pensamento analítico à sua própria experiência, Tocqueville não limitou sua visão da política à gestão racional dos interesses, afirmando que ela se dava na interação de três elementos: paixões, interesses, e normas sociais. Idéia que fundamenta sua hipótese da existência de uma correlação dinâmica entre cada regime político (a democracia, em particular) e as paixões.

Palavras-chave História, História Política, Sentimentos

ABSTRACT A great part of historical research has been remiss in studying the role of the emotions in the construction of political and social activity, a type of study that is often opposed under the accusation of producing psychological determinisms. Various trends in political history made of the emotions a strange object in their discussions, by choosing the exclusive study of the cognitive aspects of politics and by presupposing that subjects are fully conscious and rational, guided only by the impulse of satisfying their interests or through faithfulness to their ideas. And yet, new historiographical perspectives point to the possibility of joining the symbolic and affective dimensions to the study of politics. Aligning itself with the project of a social history of the political emotions, this essay evaluates these new procedures, concentrating on the approach to the sentiments that have ruled political adhesion in the modern period, as well as the rhetorical and expressive repertories associated with them. For this purpose, it begins with the examination of the expression of emotions and their uses present in the texts of a thinker who is both an actor and astute observer of the political scenario of his time: Tocqueville. Fusing analytical thought with his own experience, Tocqueville did not limit his vision of politics to the rational management of interests, arguing that that took place in the interaction among three elements: passions, interests, and social norms, an idea that bases his hypothesis on the existence of a dynamic correlation between each political regime (democracy, in particular) and the passions.

Key words History, Polical History, Sentiments

O quase completo desaparecimento da história das mentalidades da paisagem historiográfica deixou inexplorado um terreno, cuja renúncia, pelos historiadores, é muito desoladora. A parte emocional que governa a atividade social é, hoje, deixada de lado na maior parte das pesquisas. A psicologia possui uma má reputação junto à maioria dos 
historiadores, uma vez remetida, pura e simplesmente, ao desconhecido e, até mesmo, ao irracional. E, as fontes habituais nada nos diriam sobre a alma dos atores, ou só contribuiriam para nos inundar de mentiras e ilusões, entregando-nos às falsas confidências sobre as motivações de cada um. A História Social jamais deixou de cultivar uma certa desconfiança pelos protocolos de pesquisa, aos quais denegriu, acusando-os de se perderem em formas negativas de individualismo e de psicologismo.

A História Política se une, da mesma forma, a essa linha crítica. ${ }^{2}$ Ela se apóia, na maior parte de suas versões, sobre a hipótese da existência de um sujeito deliberante, consciente, racional e habitado apenas pelo impulso de perseguir seus interesses, ou pela fidelidade às suas idéias. Há, no entanto, alguns historiadores (hoje em dia mais e mais numerosos), que propuseram perspectivas mais amplas à História Política; perspectivas estas que não reduziriam mais a política à sua dimensão cognitiva, mas que, sem renunciar a esta, Ihe agregaria outras, simbólicas e afetivas. É o que se pode reconhecer no projeto de uma História Social das Emoções Políticas. Esta teria não apenas a vantagem de colocar em funcionamento um protocolo razoável, que de forma alguma leva ao posicionamento do indivíduo no centro dos processos sociais, e nem tende a reduzi-lo à condição de máquina produtora de um determinismo isento de falhas. Ela também teria a virtude de pôr em dia aquilo que normalmente é mais rechaçado, que propriamente contestado, pelo modo de atuar dos historiadores. Estes fazem, ai!, um uso vulgar e inconsciente da psicologia, que a reconduz a alguns axiomas vindos diretamente do senso comum, e faz crer que as leis que regem as emoções escapam à história.

\section{A carta roubada}

O papel dos sentimentos e dos afetos na vida política é um secret de Polichinelle, um segredo que todos conhecem. ${ }^{3}$ A despeito do sonho

2 Não é inútil salientar aqui que um dos fundadores da psicologia científica, Théodule Ribot, afirmou alto e forte: A natureza da vida afetiva não pode ser compreendida a menos que se persigam suas transformações incessantes, quer dizer, sua história. Separá-la das instituições sociais, morais, religiosas, das transformações estéticas e intelectuais que a traduzem e encarnam, é reduzi-la a uma abstração vazia e morta. (RIBOT, Théodule. La Psychologie des sentiments. Paris: Alcan, 1896. p. X.)

3 Cf. BRAUD, Philippe. L'émotion en politique. Paris: Presses de Sciences-Po, 1996. (Références inédites): 0 observador mais distraído não ignora a intensidade do desejo de poder entre aqueles que aspiram ao exercício das responsabilidades públicas, o vigor dos embates verbais entre os candidatos, nas eleições, os fenômenos coletivos de entusiasmo, de indignação ou de amargor, que colorem as manifestações de rua, os temores que suscitam a irrupção da violência, ou do terrorismo, no curso da vida social, enfim, através das mídias os usos políticos do sofrimento do outro. E, se alguém mede, com uma assiduidade conscientemennte, as cotas de popularidades, às quais, na democracia, os atores políticos dão tão grande importância, não é porque que ser amado, estimado, admirado por seus concidadãos confere uma autoridade política apreciável? Idem, p.7-8. 
recorrente de alguns, dentre os quais se encontram, sem dúvida (como mostrarei mais abaixo, a título de ilustração), o próprio Tocqueville e os teóricos do início século XIX, a política dos modernos, após a Revolução, não era inteiramente construída pela razão. A política não se nutria apenas de axiomas, e nem reservava aos mais competentes a resolução das questões mais árduas. Ela teve, como nos tempos revolucionários, sua fase inaugural, que conheceu intensos momentos de desinstitucionalização, comandados pela submissão da razão às paixões. A longa história da política contemporânea se desenrola sob o império desta dialética entre a razão, a paixão e os interesses, cujo jogo sutil convém esclarecer.

Os melhores atores políticos raramente se iludem com uma concepção serena de sua atividade profissional. Mesmo nas épocas não revolucionárias, sem dúvida menos propícias ao desenvolvimento das paixões, são incontáveis as reflexões que fazem menção à preponderância dos sentimentos sobre os argumentos. A este respeito, Joseph Caillaux disse, em um trecho de suas Memórias: Nosso país, nossos concidadãos, são mais abertos aos sentimentos, que à lógica. Eles se apaixonam, mais que raciocinam. Eles admiram os homens que Ihes parecem a expressão viva de suas aspirações confusas. Quando aprovam alguém, seguem-no aonde quer que os venha a conduzir. ${ }^{4}$ Os maiores oradores da Câmara conhecem bem os motores do sucesso político e, freqüentemente, traem um de seus segredos, a exemplo de Louis Barthou: Não se pode ser orador senão ao preço desta emoção. É preciso ter medo da tribuna, para ser indiferente à tribuna. Gambetta e de Mun, WaldeckRousseau e Deschanel, Ribot e Jaurès, para falar apenas de grandes vozes que se extinguiram, conheceram esse medo, esse tremor íntimo, esta angústia física e moral, que abala todo o ser, antes da ação. ${ }^{5}$ É ainda o que se lê nesse especialista das práticas parlamentares, que foi Georges Buisson, antigo chefe adjunto do Serviço Estenográfico da Câmara dos Deputados, ao comparar a arte da oratória de René Viviani à de Aristide Briand, para destacar uma outra ordem de funcionamento da vida política, que não apenas o confronto das idéias, regulado pela razão:

As palavras podem parecer inflamadas, mas parece que a fé não o é: o verbo pode parecer cálido, mas pode-se crer que o coração é frio; o gesto pode levar ao lirismo, e se tem a forte impressão de que artista não tem paixão. Seu olhar, sempre com uma ponta de tristeza, parece indicar que ele está perpetuamente entediado e enfadado. Ademais, a voz é surda, velada, e M. René

CAILLAUX, Joseph. Mes mémoires. Paris: Plon, 1943. p.89. (Mes audaces. - Agadir.., 1909-1912, tome 2) BARTHOU, Louis. Le Politique. Paris: Hachette, 1923. p.47. 
Viviani, que sabe de cor seus discursos, os repete em marcha, pelos corredores, os recita muito rápido, muito rápido mesmo. Com este orador, no qual, apesar de tudo, o verbo é magnífico, esse excesso de rapidez é uma falha. Com certeza, os oradores, falando com uma tal tagarelice, correm menos o risco de serem interrompidos. Como o prova, às vezes, uma certa dificuldade que se tem para seguir seu pensamento: os escutamos, mas sem os interromper.

Ao contrário, quando um orador tem uma voz cantante, cálida e cativante, quando sua locução é mais lenta, não se tem essa impressão do esforço que se há de fazer para seguir seu pensamento: ele é mais bem compreendido. É o caso de M. Aristide Briand, que tem tudo à sua disposição: a eloqüência persuasiva, a voz alternadamente grave e amável, o gesto natural e bem apropriado. Ele é, certamente, entre todos os oradores, aquele que deixa a impressão mais forte, o único que tem sangue-frio o bastante para ser, constantemente - quaisquer que sejam as circunstâncias - , senhor da velocidade de sua palavra, a fim de que se possa facilmente seguir o seu pensamento, sem fadiga, compreendê-lo bem, e estar, assim, melhor preparado para se deixar convencer. ${ }^{6}$

Estas constatações, revelando as normas próprias do mundo político, findam por condicionar toda uma forma de agir, que toma lugar nas estratégias de representação, que se fundamentam na manipulação de objetos simbólicos.

Felizmente, em meados da década de 1990, a História Política levou em conta essa dimensão da vida política. Pode-se esperar que a noção de cultura política ${ }^{7}$ favoreça este movimento, embora seja verdade que, às vezes, se faça cômodo não permitir nada além de um retorno à velha História das Idéias e dos Partidos Políticos. Daqui em diante, entende-se que a política se faz com um conjunto de signos que conclamam os reflexos identitários, não passando somente pelo reconhecimento das opiniões demandadas, ou só pelo teor ideológico do discurso. ${ }^{8}$ A adesão mobiliza todo um conjunto de processos complexos, que jamais se esgotam na cognição, mesmo em se tratando dos mais racionais dos interesses. É esta parte emocional, que preside a constituição do vínculo político, que convém abordar numa perspectiva histórica.

Se, agora, os historiadores começam a conhecer melhor os mecanismos simbólicos que impulsionam a vida política, como mostra o crescente aparecimento de trabalhos consagrados aos rituais políticos (manifestações, funerais, viagens presidenciais, protocolos, etc. ), ${ }^{9}$ ainda são

6 BUISSON, Georges. La Chambre des deputes. Paris: Hachette, 1924. p.138-139.

7 Ver: BERSTEIN, Serge (org.). Les cultures politiques en France. Paris : Seuil, 1999.

8 É isto que aborda o número especial, consagrado ao caso Dreyfus, da revista Mil neuf cent. Revue d'histoire intellectuelle, 11, 1993. (Comment ils sont devenus dreyfusards).

9 A título de ilustração, as obras mais recentes são: TARTAKOWSKY, Danielle. Les Manifestations de rue en France, 1918-1968. Paris: Publications de la Sorbonne, 1997; ROBERT, Vincent. Les Chemins de la 
poucas as tentativas de se estudar os motores emocionais destas práticas, e mesmo os fenômenos de apropriação ou de recepção de que são objeto. Não restam dúvidas que tal empreitada esbarra em sérios obstáculos conceituais e metodológicos. A História das Mentalidades Ihe foi, desde sempre, contrária, e as bricolagens às quais recorreu não foram de todo convincentes. A redução do estudo histórico dos sentimentos a uma aproximação com a História Literária não responde às exigências de tal investigação, mesmo que as molduras oferecidas pela alta cultura tenham peso sobre o conjunto da sociedade. Mas, não é menos verdadeiro que haja algumas tentativas que conduzam bem essas questões. Algumas surgiram mais por outros domínios, que pela vida política. Citemos, entre outros exemplos possíveis, a profissão de fé que Jean-Louis Flandrin fez na portada de uma obra, que repercute na crista desta onda historiográfica:

Os sentimentos pertencem, de fato, à natureza? Compreenderíamos facilmente os sentimentos dos homens do passado pela simples razão de que somos homens e portamos em nós toda a natureza humana? É o que disseram os clássicos e o que parece ainda pensar a maior parte dos historiadores. Da minha parte, parto de uma convicção contrária: não há compreensão possível do que sentem os outros, tanto quanto se permanece estrangeiro à consciência que têm. Pode-se descrever a aparência de uma conduta suas manifestações externas -, em termos atuais; pode-se estabelecer estatisticamente as relações aparentes entre os estímulos e os comportamentos, e isso é de uma utilidade incontestável; mas, não se pode aproximar a realidade humana de uma conduta senão através da consciência que os sujeitos têm dela.Logo, o acesso à interioridade do sujeito não está irremediavelmente fechado ao estudo científico. Para ser final e irredutivelmente original, cada conduta individual não deixa de ser menos amplamente determinada pela cultura onde se manifesta. Pois nossas pulsões não se realizam a não ser tomando as formas características de uma determinada cultura; nossos sentimentos não nos são perceptíveis, a menos que se encerrem em palavras, nas imagens que esta cultura nos oferece. É dessas formas que deve partir uma explicação histórica da realidade psíquica. ${ }^{10}$

A História Política da França contemporânea não está completamente à parte desta agenda, que agora parece se impor progressivamente. A dimensão sensível do vínculo político faz parte das inquirições daqueles que observam e analisam a política; ainda que, sem dúvida, de forma muito insuficiente, como o observou Philippe Braud. ${ }^{11}$ Pode-se dizer que

manifestation (1848-1914). Lyon: PUL, 1996; AMOS, Avner Bem. Funerals, Politics, and Memory in modern France, 1789-1996. Oxford: Oxford University Press, 2000; JULLIARD, Jacques (org.). La mort du roi. Essai d'ethnographie politique comparée. Paris: Gallimard, 1999 ; MARIOT, Nicolas. Propagande par la vue, souveraineté régalienne et gestion du nombre dans les voyages en province de Carnot (1888-1894), Genèses, septembre, 1995.

10 FLANDRIN, Jean-Louis. Le sexe et l'Occident. Evolution des attitudes et des comportements. Paris: Seuil, 1981. p.21.

11 BRAUD, Philippe, L'émotion en politique, op.cit., p.7. 
as tradições sociológicas e etnográficas francesas recalcam a questão dos sentimentos (mesmo que, como entre os historiadores, esse recalque permaneça incompleto), à exceção de alguns casos, entre os quais estão certos estudos em que Marcel Maus desejava por em evidência as montagens fisio-psico-sociológicas das séries de atos; ${ }^{12}$ ou ainda o exemplo isolado da obra clássica de Pierre Ansart, inscrita na esteira de um Montesquieu, segundo o qual cada sistema político dispõe de um modelo de paixão que faz eco à sua estrutura e seu funcionamento. ${ }^{13} \mathrm{Em}$ um registro diferente, na obra de Alain Corbin, ${ }^{14}$ ou, mais recentemente, em Pierre Rosavallon (que fez da decepção o impulso maior da história da democracia), ${ }^{15}$ os afetos fazem parte do horizonte analítico dos historiadores da política.

Nos Estados Unidos, esse movimento é mais claro. Inúmeros historiadores abordaram frontalmente a questão das emoções. Robert Nye e, mais recentemente, William Reddy se apropriaram da questão do papel desempenhado pela honra, na França contemporânea. ${ }^{16}$ Estes dois autores resgatam os sistemas sensíveis nos quais os indivíduos se inscrevem, e através dos quais experimentam suas emoções: nem de todo livres, nem totalmente submissos aos códigos que os precedem, os indivíduos organizam um espaço emocional próprio (agency). Trata-se aqui, portanto, de uma Historia Sócio-Cultural, e não de uma psicologia histórica qualquer, feita de solipsismo. ${ }^{17}$ Edward Berenson, por sua parte, deu toda a importância ao papel das emoções, no estudo do processo Caillaux, que foi ao mesmo tempo uma questão política e uma questão de honra, em um período em que, todavia, os processos de modernização da política faziam crer que tais afetos remetiam a um tempo já passado. ${ }^{18}$ Fica claro, portanto, que Madame Caillaux queria lavar a honra de seu marido, manchada por uma campanha da imprensa. Da mesma forma, há toda uma corrente que ativa tais problemas, no seio da ciência política, que é rica de novas perspectivas para os historiadores da políti-

12 MAUSS, Marcel. Les techniques du corps (1935), reeditado em Sociologie et anthropologie. Paris: PUF, 1950. p.382.

13 ANSART, Pierre. La gestion des passions politiques. Lausanne: L’Age d'homme, 1983. Convém, também, salientar o desenvolvimento, nas décadas de 1980 e 1990, de uma verdadeira sub-disciplina, sobretudo nos Estados Unidos, que é a antropologia das emoções. Cf. BRETON, David Le. Les passions ordinaires. Anthropologie des émotions. Paris: Colin/Masson, 1998.

14 CORBIN, Alain. Le village des cannibales. Paris: Aubier, 1991. Cf. AGULHON, Maurice. Fête spontanée et fête organisée à Paris en 1848. In: EHRARD, Jean; VIALLANEIX, Paul (org.). Les fêtes de la Révolution. Paris: 1977.

15 ROSANVALLON, Pierre. La démocratie inachevée. Histoire de la souveraineté du peuple en France. Paris: Gallimard, 2000. p.28.

16 NYE, Robert A. Masculinity and Male Codes of Honor in Modern France. Oxford University Press, 1993; REDDY, William M. The Invisible Code. Honor and Sentiment in Postrevolutionary France, 1814-1848. Berkeley: University of California Press, 1997.

17 Cf. REDDY, William M. Emotional Liberty: Politics and History in the Anthropology of Emotions, Cultural Anthropology, 14-2, 1999.

18 BERENSON, Edward. The Trial of Madame Caillaux. Berkeley; Los Angeles: University of California Press, 1992. 
ca. Um dos mais ativos fomentadores da psicologia política, Jon Elster (sobre o qual voltarei, em função de sua importância ao relacionar Tocqueville ao ponto de vista de que me ocupo), abordou as emoções como sendo a matéria-prima, o combustível (as fuel, raw meterial) ${ }^{19}$ que alimenta a História Política, com os mesmos direitos que as idéias e os interesses. Além disso, Elster afirmou ser Aristóteles, à sua maneira, uma espécie de ilustre precursor: sua compreensão da política ateniense passava por um estudo das emoções que a dirigiram, a começar, segundo ele, pelas duas principais: a cólera e o ódio.

Portanto, é preciso, em primeiro lugar, tentar esclarecer o que entendemos por emoção, antes de aplicar essa noção no exame da política contemporânea. Emoção encontra seu equivalente no velho sentido da palavra paixão, que designa o conjunto de movimentos afetivos, mais ou menos estáveis, engendrados pelo choque de um estado individual com a análise de uma situação. Isto implica em duas conseqüências importantes: as emoções não resultam de um encaminhamento puramente individual, mas se inscrevem em uma perspectiva social e cultural; elas não se opõem à cognição. Torna-se necessário recordar do caso de Tocqueville. Ao se estudar as emoções, não se busca tomar o homem a nu. Os impulsos ocultos de sua alma estão definitivamente vedados aos historiadores, como também a seus contemporâneos, quaisquer que sejam as pretensões de alguns dentre eles. Em compensação, existem meios para a apreensão e o estudo dos registros da expressão das emoções, como também aquilo a que chamarei de práticas emocionais, que visam a desencadear os usos das emoções. Estas são as questões úteis aos historiadores, e aquelas às quais eles podem tentar responder sem se arriscarem demais a cair nas armadilhas do psicologismo: Como se expressa aquilo que se designa por ódio, amor, amizade, honra, etc.? Quais repertórios retóricos e quais manifestações físicas correspondem a estas emoções, segundo os momentos históricos a que concernem, e quais as molduras sócio-culturais (as culturas políticas, a que nos referimos aqui) são considerados? Quais são os códigos que estabelecem a decência e a indecência da exposição das emoções humanas? Quais são toleráveis, e quais não são? Que usos são dados às emoções? Como se pode utilizar a afirmação de sua fraqueza (as lágrimas, às vezes), ou de sua força (o riso, a cólera, etc.)? Tal programa haveria de incluir a plena substituição de uma história das práticas sociais. Ele vai de encontro à hipótese desta, que se assenta na transparência completa dos textos, supondo que neles as emoções são expressas livremente, sem mediação dos movimentos da alma e dos estados psicológicos, os quais não teriam uma história.

19 ELSTER, Jon. Alchemies of the Mind. Rationality and the Emotions. Cambridge: Cambridge University Press, 1999. p.IX. 
Preferir emoção a sentimento permite dissipar ainda mais toda tendência a se elaborar uma história da sinceridade dos atores. A expressão de um sentimento não é sempre, e nem somente, uma confissão, que nos informa diretamente sobre o estado psicológico daquele que a realiza. William Reddy observa justamente essa dimensão performática, da qual os melhores atores políticos têm perfeita consciência, visto que estabelecem os limites de seus discursos em função dos efeitos que pretendem produzir, para além do que querem dizer. Assim, afirma Reddy, em uma perspectiva muito geral, ao se declarar um sentimento, podese visar à produção de um efeito no próximo, que se dá não apenas pela palavra, mas também através de outros tipos de encenações, como os sorrisos, o pranto, etc. Este efeito pode ser também auto-persuasivo: se a confissão nem sempre reflete a verdade, ela pode ter conseqüências sobre aquele que a pronuncia, revelando-lhe, precisamente, uma verdade ou uma mentira (em te dizendo que te amo, me dou conta se te amo ou não, independentemente do que senti, antes de afirmá-lo nesta confissão). ${ }^{20}$

Distinguindo duas categorias de emoção — as que se animam a partir da comparação com os outros (motions of comparison) e aquelas que resultam de uma interação (motions of interaction) - , Jon Elster também situa essa investigação no terreno social, se recusando a associar a análise das emoções políticas à psicologia dos atores, tal como defendem, simultaneamente, uma forte tradição americana de psicologia política, ${ }^{21}$ e uma historiografia francesa que se apóia no inventario biográfico da vida política. Das inúmeras objeções feitas ao gênero biográfico, tal como é mais freqüentemente empregado, ${ }^{22}$ não se faz necessário que nos detenhamos em outra que não a discussão sobre o psicologismo que the domina. Os vestígios esparsos de que os historiadores dispõem não podem fundamentar a reconstituição de um perfil psicológico (cuja própria noção é discutível), quando somente se tem por horizonte o individualismo contemporâneo. Por outro lado, é perfeitamente possível analisar o complexo emocional que interage com o indivíduo. Nesse caso, é lícito examinar seus modos de inserção em um universo emocional singular, e a gestão das paixões que lhe é própria. Ir além seria ingênuo. Todas as observações precedentes visam a enquadrar, para um

20 REDDY, William M. Sentimentalism and Its Erasure: The Role of Emotions in the Era of the French Revolution, The Journal of Modern History, 72, march 2000, p.164.

21 Ver a explicação dada em GLAD, Betty. Political Psychology: Where have we been? Where are we going? In: CROTTY, William (org.). Political Science. Looking in the Future. Evanston: Northwestern University Press, 1991. p.347-363. (vol. III). ROBINS, Robert; POST, Jerrold. Political Paranoïa: The Psychopolitics of Hatred. New Haven: Yale University Press, 1997, atribui, a despeito de suas negações, um papel considerável à psicologia dos atores.

22 Para uma explicação recente, ver: CANDAR, Gilles. Le statut de la biographie. Essai de chronologie, Correspondances, 61, p.11-16, mai-juillet 2000. 
melhor controle, o estudo histórico das emoções na vida política pósrevolucionária. Tal programa de pesquisa está em curso. Os estudos começam a se multiplicar, sobretudo para o século XIX. Num primeiro momento, uma das formas de contribuir, evitando muito facilmente os obstáculos assinalados, seria examinar o lugar dado às emoções na visão que um contemporâneo (que é, ao mesmo tempo, ator e observador) sustenta acerca da vida política de seu tempo. Essa não é mais que uma etapa de um estudo que também deverá se aproximar frontalmente das emoções e, se possível, do momento exato do surgimento de sua expressão. Fontes não faltam. De alto a baixo da vida política, elas podem ser tomadas tanto no seio do jogo parlamentar, quanto nos meandros de um grafite; tanto nas memórias e lembranças dos homens de política, onde ao fim se desenlaça toda uma história, como em pleno coração dos arquivos judiciários, onde jaz todo um discurso político que não é isento de importância. Trata-se apenas de dar uma nova atenção a textos tão freqüentemente lidos, e tão apressadamente comentados, para assim revelar uma parte do segredo da política num regime democrático.

\section{Tocqueville, psicólogo da política}

Afirmando que Tocqueville é o maior pensador político do século $X I X$, Jon Elster observou que nele os detalhes são mais interessantes que o todo, os raciocínios mais potentes que as conclusões, os mecanismos parciais mais inabaláveis que as teorias gerais. ${ }^{23}$ Uma leitura minuciosa (close reading) dos textos de Tocqueville revela imediatamente a importância do autor de A Democracia na América, frente aos métodos psicológicos de explicação dos fenômenos políticos e sociais. Esses mecanismos constituem, como salientou Elster, blocos elementares de explicação. ${ }^{24}$

Há, simultaneamente, em Tocqueville, um moralista do grande século e um observador político, tal como o espírito positivo do século XIX desde cedo o definiu. A análise das paixões como fonte de energia primordial da vida social, e alguns aforismos (notadamente em A Democracia na América), ao se ocuparem da dialética das paixões e dos interesses, ancoram Tocqueville ao passado. Em compensação, sua tentativa de compreender em termos universais, e, portanto, de forjar universais psicológicos capazes de aparelhar aquele que quer compreender uma determinada situação histórica, o enraíza em seu século, e até mesmo no seguinte. $O$ fato que Tocqueville ponha em evidência as possibilida-

23 ELSTER, Jon. Psychologie politique (Veyne, Zinoviev, Tocqueville). Paris: Éditions de Minuit, 1990. p.101.

24 Idem, p.102. 
des permanentes, mais ainda que as leis, e que, assim, fuja ao risco do determinismo (que foi o pedestal do pensamento marxista), nos ajuda a compreender sua fortuna junto aos historiadores pós-marxistas. Tocqueville não é monocausal, nem simplista, nas explicações que traz. Em $A$ Democracia na América, três instâncias comandam a ordem social: as paixões, os interesses e as normas sociais. Resulta que, em geral, Tocqueville parece abandonar freqüentemente os conflitos de interesse para se deter, acima de tudo e em primeiro lugar, na paixão que se apodera dos homens. Ele quase não crê na deliberação, tal como fora sonhada pelos liberais de seu tempo, ansiosos por verem nascer uma política que se limitaria à gestão racional dos interesses de todos, e que seria confiada a homens de razão, indiferentes, ou quase, às emoções da política. ${ }^{25}$

A psicologia social de Tocqueville, é preciso lembrar, se fundamenta sobre certos pressupostos, que se nutrem de sua experiência da história. Este intelectual é também um aventureiro. Seus livros são povoados de lembranças e emoções pessoais, sobre as quais repousam todos seus desdobramentos, ainda que, salvo certas expressões notáveis, suas atitudes instintivas e emocionais sejam muito freqüentemente dirigidas). ${ }^{26}$ A busca, à maneira de todos aqueles que procuravam deixar a Revolução durante a desconstitucionalização da política, de um sistema político pacífico caracterizado por dar livre curso às paixões, havia produzido acontecimentos tão aterradores que Toqueville manifesta a maior prevenção contra as paixões. Incluindo, aqui, as suas próprias, observa Elster! Em Tocqueville, as paixões não desempenham, senão muito excepcionalmente, um papel positivo. Os adjetivos que ele lhes atribui são, muitas vezes, negativos: as paixões são cegas, surdas, imponderadas. Elas revelam a renúncia à vontade.

Os dois significados que ele atribui à palavra também atestam essa concepção. A paixão oculta um desejo muito forte de se obter um bem material. Ela pode ser, também, o fruto de um desejo não orientado para o favorecimento pessoal, que desvia os homens da persecução de seu interesse pessoal. Assim, ele toma, por exemplo, a paixão pela igualdade: a paixão pela igualdade penetra, por todos os lados, o coração humano, ali ela se distende, ela o preenche inteiramente. Não há um ponto nos homens que se entregue tão cega e exclusivamente à uma paixão, eles comprometem seus mais caros interesses; ficam surdos. Nem Ihes mostrando a liberdade, que Ihes escapa pelas mãos, enquanto olham para outro lado; eles ficam cegos, ou antes, não distinguem, em todo o universo, senão apenas um bem digno de desejo. ${ }^{27}$ Com justa razão,

\footnotetext{
Cf. ROSANVALLON, Pierre, op.cit., p.95-126.

26 ELSTER, Jon. Psychologie politique..., op.cit., p.111.
}

27 Citado por: ELSTER, Jon, idem, p.151. 
Elster levanta uma segunda distinção, feita por Tocqueville: a distinção entre as paixões impulsivas, paixões passageiras que se extinguem tão rapidamente quanto se acendem; e as paixões sociais, mais estáveis, que mantém as normas sociais, e que, aliás, pode-se chamar de sentimentos, o pensável ou a utensilagem mental de uma dada sociedade.

Uma das hipóteses mais interessantes de Tocqueville é a correlação que supõe entre um regime político (no caso, a democracia), e uma gestão particular das emoções. Os sentimentos são associados às formas políticas. A democracia dispõe, deste modo, de um repertório e de um regime emocional próprios, que a distinguem de qualquer outra configuração política. Esse ponto de vista encontra-se ancorado na análise que Tocqueville faz do sentimento democrático da vontade, na qual se misturam preconceitos de classe e a busca erudita pela arquitetura cultural de uma sociedade política. São bem conhecidas as duras disposições de Tocqueville contra o gosto depravado de igualdade, que mina os princípios da liberdade e conduz à aceitação final da servidão. É o desejo que trabalha, em surdina este modelo político, e o conduz fatalmente à sua falência. O desejo é um fator de aceleração da vida econômica e social, e associa a democracia ao gosto pelo imediato, à ditadura do presente. Convém assinalar, também, que tais seqüências históricas associam-se, por si mesmas, aos regimes emocionais; como, aliás, esses últimos o fazem em relação às fases sócio-políticas: cético com a política, como o século XIX, escreveu Tocqueville, em Souvenirs. ${ }^{28}$

Distingue-se muito mal, na análise das emoções conduzida por Tocqueville, quem comanda quem. Quem vem primeiro? As paixões humanas estão na origem dos sistemas políticos e sociais? Ou são estes últimos que engendram os estados psicológicos? E, que papeis são atribuídos aos interesses, cujo peso Tocqueville não ignora em sua teoria da ação? A resposta a que ele chega não permanece livre de ambigüidades. Ele defende a idéia de uma relação dinâmica entre as paixões e os sistemas políticos aos quais se associam. Em meio à Quarta Parte de $A$ Democracia na América, quando a América não é, aliás, propriamente o objeto do livro, mas sim um reservatório de exemplos a fim de se refletir sobre a liberdade nas sociedades igualitárias, ele enuncia, antes de encerrar sua investigação: Eu cumpriria mal o objetivo desse livro se, depois de ter mostrado as idéias e os sentimentos que a igualdade sugere, não fizesse ver, ao fim, qual é a influência geral que esses mesmos sentimentos e essas mesmas idéias podem exercer sobre o governo das sociedades humanas. ${ }^{29}$ É com razão que Philippe Braud fez a seguinte

28 TOCQUEVILLE, Alexis de. Souvenirs. Paris: Gallimard; Folio, 1964. p.15.

29 TOCQUEVILLE, Alexis de. De la démocratie en Amérique. (première édition : 1840). Paris: Gallimard; Folio, 1961. p.394. 
observação: Mas, Tocqueville vai muito além dessas anotações, que the inspiram um sentido psicológico particularmente acurado. Ele procura resgatar as lógicas sociais que subentendem o jogo cruzado dos interesses, das paixões e das normas culturais, jurídicas ou políticas. ${ }^{30} \mathrm{~A}$ segunda (Influência da democracia sobre os sentimentos dos americanos), e a quarta parte (Da influência que exercem as idéias e os sentimentos democráticos sobre a sociedade política) de sua enquete americana o demonstram muito claramente. É o que ele mostra na comparação que faz entre a democracia americana de seu tempo e o sistema medieval; onde distingue duas relações com o tempo, que são decisivas, como explana, para a construção dos sentimentos e dos comportamentos sociais:

Na Idade Média, quase todas as terras se encontravam perpetuamente arrendadas, ou, ao menos, a muito longo prazo. Quando se estuda a economia doméstica desse tempo, vê-se que os arrendamentos de 99 anos eram mais freqüentes que os de doze o são, em nossos dias. [...] Nos séculos de igualdade, o espírito humano toma um outro contorno. Ele se afigura facilmente de que nada é permanente. A idéia da instabilidade se apodera dele. Com esta disposição, o proprietário e o próprio arrendatário ressentem de um tipo de horror instintivo pelas obrigações à longo prazo; eles têm medo de se encontrarem, um dia, restringidos pela convenção de que tiram proveito, no presente. Eles contam vagamente com qualquer mudança, repentina ou imprevista, em sua condição. Eles temem a si mesmos; temem que se seu gosto vier a mudar, não se afligiriam por não poder dispensar aquilo que seria o objeto de sua cobiça; e eles teriam razão de receá-lo, pois, nos séculos democráticos, o que há de mais instável no meio do movimento de todas as coisas, é o coração do homem. ${ }^{31}$

Embora não se possa decidir o que comanda a ação e intervem sobre os comportamentos políticos, tem-se o fato de que Tocqueville descreve o que Jon Elster chamou de mecanismos. Não há, em Tocqueville, leis da história nem um determinismo único, mas um feixe de forças que intervêm nas configurações dadas. As emoções têm aqui um lugar, sem dúvida, muito importante, mas elas não nascem e nem se expressam a não ser através de relatos individuais. Assim, observa Tocqueville, os homens que vivem nas democracias amam seu país da mesma maneira que amam a si mesmos, transportando, deste modo, os hábitos de seu orgulho privado para seu orgulho nacional. Mas, esse transbordamento (Elster) do privado no público, de uma ordem emocional em outra, conhece muitas variantes: o americano tem em si o amor pela ordem, que ele transporta para as questões de Estado, enquanto

30 BRAUD, Philippe. L'émotion en politique, op.cit., p.51.

31 ELSTER, Jon. Psychologie politique..., op.cit., p.146. 
o europeu se consola de seus desgostos domésticos perturbando a sociedade. Se, cada regime político parece ser dotado de um sistema emocional particular, se os próprios partidos reúnem características comuns, estas dimensões psicológicas gerais da política se submetem às adaptações que Ihes sujeitam as sensibilidades e as culturas nacionais. Resta que Tocqueville dá grande importância às emoções coletivas, as emoções dos grupos naturais (homens-mulheres), das classes, das regiões (o ódio que Paris inspira às províncias), das instituições (a Assembléia é resoluta ou inquieta), das nações e dos partidos, que são as mais temíveis e as ativas nos episódios de crise política. Elas parecem, então, fundar um vínculo entre os indivíduos. Em fevereiro de 1848, pela primeira vez depois de sessenta anos, observa o autor de Souvenirs, os padres, a antiga aristocracia e o povo se reencontravam em um sentimento comum, sentimento de rancor, é verdade, e não de afeição comum. Nem por isso esse sentimento dispõe de uma menor eficácia social, segundo um princípio que Tocqueville nos lega, sob a forma de uma de suas máximas, cujo estilo é, sem dúvida, o de um moralista do grande século: em política, afirma ele, a comunidade dos ódios está quase sempre no âmago das amizades. ${ }^{32}$

\section{O caso de Souvenirs}

Tocqueville escreveu seus Souvenirs em julho de 1850, pouco depois de ter deixado suas funções de Ministro de Assuntos Estrangeiros, que ocupou na República, de 3 de junho a 29 de outubro de 1849. Naturalmente, não seria necessário cair na armadilha que o antigo ministro armou para seus futuros leitores. Com efeito, ele apresenta seu texto como se jamais devesse ter sido entregue ao público, asseverando, portanto, sua absoluta sinceridade. Segundo seus dizeres, reconstituídos por ele próprio, seus Souvenirs estão, no entanto, cheios de falsas confidências. E, estas não comportam menos que uma propriedade: a de nos apresentar uma tentativa de explicação dos acontecimentos políticos recentes (as revoluções de fevereiro e de junho de 1848, e seus desdobramentos), desalojando os motivos secretos que teriam dominado a ação dos homens que deles se encontravam tomados: Eu quero, sinceramente, descobrir quais são os motivos secretos que nos fazem agir (a eles e mim mesmo, como a todos os homens), e, os havendo compreendido, os expor. ${ }^{33}$ Entre estes, as pequenas paixões dos homens não seriam as últimas, permeando as idéias e os projetos de cada um. Em Souvenirs se destaca, também, o regime emocional que governa o próprio Tocquevi-

32 TOCQUEVILLE, Alexis de. Souvenirs, op.cit., p.99.

33 Idem, p.11-12. 
Ile, e que comanda sua análise dos acontecimentos políticos que observa, e daqueles de que participa.

As paixões se apresentam, sem dificuldade, como o combustível (fuel, diria Elster) das peripécias revolucionárias. Tocqueville insiste bastante quanto ao temor experimentado pela classe política, nos dias de fevereiro, sobretudo por aqueles que se engajaram à frente da desordem. Haveriam avaliado bem os perigos que o furor do povo faria percorrer por toda a nação? A história não haveria de escapar ao controle das classes dirigentes: às vésperas do incidente, Mme. de Lamartine, indo visitar Mme. de Tocqueville, Ihe demonstrou uma ansiedade tão extraordinária, deixando-se ver com um espírito exaltado e quase perturbado por idéias tão sinistras, que essa ficou emoconada, me comunicando o fato naquela mesma noite. ${ }^{34}$ Tocqueville partilha dos preconceitos de seu tempo: ele atribui às mulheres as paixões mais exasperadas, de acordo com a imagem que tanto a massa, quanto as classes, delas faziam. No entanto, elas desempenharam, na revolução, um papel de primeira ordem: podese dizer que tais mulheres trouxeram ao combate as paixões de donasde-casa; elas tiveram importância para a vitória por haver dado comodidade a seus maridos, e por criarem suas crianças. Elas estimavam esta guerra como estimariam uma loteria. ${ }^{35}$ Esta característica psicológica atribuída às mulheres as afasta da razão - atributo maior, que Tocqueville gostaria tanto de ver preenchendo a política -, o que explica porque a mais honesta das mulheres é, muitas vezes, a mais medíocre das cidadãs.

Aderindo ao sonho liberal de uma política pacífica, Tocqueville fez das paixões a própria causa das derivas revolucionárias. Elas são defeitos, e desempenham sempre um papel negativo. É bem raro surpreender, nos Souvenirs, uma paixão positiva. Aqui, uma confissão Ihe escapa, posto que parece conceder às paixões uma função útil: não são as paixões, seguramente, que me faltam; mas, na tribuna, a paixão de falar bem sempre extingue em mim, momentaneamente, todas as outras. ${ }^{36} \mathrm{O}$ único adjetivo elogioso que Tocqueville atribui à paixão é ser verdadeira. Por exemplo, ele encontra algumas paixões deste tipo, e as celebra, no retrato que esboça de Duvergier de Hauranne; no qual, entretanto, lastima todos os defeitos que o espírito de partido pode ter. Tocqueville reconhece em Duvergier de Hauranne o tipo de desinteresse e a sinceridade que se encontram nas paixões verdadeiras, duas qualidades raras em nossos dias, quando quase não há outra paixão verdadeira que a paixão por si mesmo. ${ }^{37}$ Todavia, essas paixões verdadeiras, ou verídicas, não 
têm, muitas vezes, virtudes outras que serem sinceras. Uma paixão verdadeira não é encenada: o que pode fazê-la até mais temível. Aos olhos de Tocqueville, a sinceridade permanece um critério importante, permitindo-lhe medir a importância dos fenômenos que descreve: a sinceridade dos homens, para compreender o sentido de suas ações (eu jamais teria conhecido um espírito menos sincero, escreveu ele, a propósito de Lamartine);38 a sinceridade das massas, para apreciar seu grau de união, como por ocasião da primeira reunião da Assembléia, em 4 de maio de 1848, em entendimento aos gritos de Viva a República!: creio, de resto, que aqui o grito foi, de ambos os lados, sincero; ele respondeu somente a pensamentos diversos, ou mesmo contrários. Todos queriam, nesse momento, conservar a República, mas, disso, uns se utilizaram para atacar, outros para se defender. Os jornais da época falaram do entusiasmo da Assembléia e daquela multidão; houve muito barulho, mas sem entusiasmo. Alguns estavam muito preocupados com o dia de amanhã, para se deixarem arrastar muito longe deste pensamento, por um sentimento qualquer. ${ }^{39}$

Não seria surpreendente, portanto, ver Tocqueville entender os aspectos da façanha revolucionaria de 1848, em sua dimensão mais emocional, como um jogo teatral, no qual as emoções de uns e de outros resultam, acima de qualquer coisa, em um desejo de imitação. Em 1848, os atores políticos ainda estão cheios de lembranças da grande revolução; lembranças estas que foram, muito freqüentemente, apropriadas pelo filtro da literatura, primeiro vetor emocional: A História da Revolução, de M. Thiers, Les Girondins, de M. de Lamartine, e outras obras menos célebres, mas muito conhecidas, e sobretudo as peças de teatro, tinham reabilitado o Terror e, de certo modo, o colocaram na moda. Assim, se fizeram falar, na língua inflamada de 93, as paixões mornas da época, e citava-se, a todo momento, o exemplo e o nome de ilustres facínoras, com os quais não se tinha nem a energia, nem mesmo o desejo sincero de se parecer. ${ }^{40}$ Sabe-se que o decreto do governo provisório, que exigiu dos deputados o uso dos trajes convencionais, jamais foi aplicado, e que sempre houve algo de irrisório na terminologia retomada pelos montanheses. Mas, para Tocqueville, este reaquecimento súbito de uma história arrefecida não foi insincero: ele prenunciou, em fevereiro, acontecimentos muito mais trágicos, que se desenrolariam em junho. Embalados por estas lembranças, das quais se apropriaram, os revolucionários de 1848 terminaram por reviver as emoções de 93.

Muito freqüentemente, as paixões convivem com a loucura: paixões

38 Idem, p.146.

39 Idem, p.136.

40 Idem, p. 100. 
cegas ou inimigas, como declarou Louis-Philippe, na abertura da seção de 1848, designando aquelas que habitavam os organizadores de banquetes; paixões ambiciosas, completou Toqueville, evocando as mesmas paixões, que conduziriam estes últimos à perda da razão. As paixões são sempre dominantes, egoístas, e se relacionam com os sentimentos violentos que os loucos cultivam: a cobiça (que alimenta antes de tudo a guerra entre classes), a surpresa, a cólera, o medo, a inveja, o orgulho e a ambição, que Tocqueville lê nas faces dos deputados, no dia seguinte à queda de Guizot. Posto que a luta de classes não se reduz a um enfrentamento entre interesses antagônicos, e que é trabalhada por todo um repertório de emoções, o socialismo não é pouco mais que um resumo das paixões populares. E ele também se opõe ao liberalismo doutrinário, que aspira a regular, com prudência, a administração das coisas. Para Tocqueville, as revoluções se apresentam, aliás, como momentos de loucura, já que a política se desinstitucionaliza e escapa a seus dirigentes habituais: estas grandes emoções públicas formam um tipo de atmosfera ardente em meio a todas aquelas paixões particulares, que se excitam e oscilam. ${ }^{41}$ Então, os acontecimentos se prestam a serem tomados pelos mais exaltados, aqueles cujos sentimentos são mais próximos aos dos loucos. É esta a análise apresentada acerca do dia 15 de maio, quando a Assembléia foi invadida pelo povo, como se as paixões tivessem vindo desordenar a razão:

Fui abordado, em meio a este tumulto, por Trélat, revolucionário de gênero sentimental e sonhador, que havia conspirado a favor da república, durante toda a época da monarquia, de resto, médico de mérito que dirigia, naquele tempo, um dos principais hospitais de loucos de Paris, ainda que fosse ele próprio um pouco maluco. Ele me tomou as mãos efusivamente, e com lágrimas nos olhos: Ah! Senhor, diga-me, que infelicidade e quão estranho é pensar que são estes os loucos, que os verdadeiros loucos levaram a isto! Eu operei ou tratei de todos eles. Blanqui é um louco, Barbès é um louco, Sobrier é um louco, Huber, sobretudo, é um louco; todos loucos, senhor, que deveriam estar em meu Salpétriére, [nome do Hospital] e não aqui. Ele teria, seguramente, se juntado à lista, caso se conhecesse tão bem, quanto conhecia a seus velhos amigos. Tenho sempre pensado que nas revoluções, sobretudo nas revoluções democráticas, os loucos, não apenas aqueles aos quais se dá esse nome por metáfora, mas os verdadeiros, exercem um papel político muito considerável. O certo é que, no mínimo, uma semi-loucura não é inconveniente nesse momento, e serve freqüentemente ao sucesso. ${ }^{42}$

A importância que Tocqueville atribui às emoções na análise geral da política (e, em particular, na da revolução) reside, também, no estilo 
dos retratos que desenha dos principais atores. Em alguns deles, ele dá a conhecer tanto os traços psicológicos, quanto as opiniões, os interesses e as competências. Tema que já evoquei, a propósito de Duvergier de Haurenne, esboço psicológico no qual se delineia uma definição das paixões verdadeiras. Por outro lado, pode se reconhecer que estas evocações sublinham as forças e fraquezas dos indivíduos, dando conta de seus êxitos e de suas falhas: a coragem e a ausência de paixões brutais, em Louis-Philippe, e em Dûchatel, seu Ministro do Interior; a loucura de Barrot e de Thiers, que o tomou no perigo dos acontecimentos de fevereiro (eles se tornaram quase loucos, nos afirma Tocqueville); ou, no Duque de Nemours, a coragem firme, taciturna, estéril e terna (pois o refinamento das categorias psicológicas é grande em Tocqueville, quem sempre analisa as personalidades em ação). Ainda mais interessantes são as observações feitas acerca de Ampère, seu colega no Instituto, ao qual Tocqueville censurou por trazer para a política o espírito literário: isto a que chamo espírito literário na política consiste em ver o que é engenhoso e novo, mais que o que é verdadeiro, amar o que faz um quadro interessante, mais que o que serve à se mostrar muito sensível ao bom desempenho e ao bem falar dos atores, independente das conseqüências da peça, e, enfim, a optar pelas impressões, mais que pelas razões. ${ }^{43}$ Este defeito teria levado Ampère a ser tomado pela emoção popular. Estava aí, também, um dos traços os mais nítidos da cultura política nacional, que afligiu o liberal racional que Tocqueville gabava-se de ser: não poder garantir à razão suas prerrogativas na política!

Sua censura à intrusão das emoções no julgamento e na ação política não elimina sua presença ativa na análise dos acontecimentos. Tudo se passa como se isso devesse ajudar Tocqueville a restringir, se não a eliminar totalmente, a parte emocional que veio a obscurecer a serenidade de sua observação. Deste ponto de vista, o autor de Souvenirs é muito semelhante aos outros, não correspondendo, de forma alguma, à imagem que tenta transmitir ao leitor (ou a si mesmo, se dermos crédito à sua declaração inicial, acerca de seu desejo de não haver redigido suas lembranças, senão que para si próprio). Em Tocqueville, como em muitos dos atores políticos que evoca, a razão jamais é pura, e se avizinha perigosamente das paixões e dos interesses. Na obra de Tocqueville, tanto uns, quanto os outros, encontram boa parte de sua origem nos hábitos do senhor de Tocqueville.

Pode- se avaliar bem as reações que se espalham pelos Souvenirs. Particularmente uma, dentre todas, merece atenção. Ela revela o compromisso que Tocqueville devia ter para com a república e o estabeleci-

43 Idem, p.91. 
mento da soberania popular. Rapidamente, ele se conscientizou que este regime era o reino das emoções. Caso se desejasse desempenhar sua parte, conviria aceitar as regras, arriscando-se a pervertê-las: não seria muito repetir, os discursos são feitos para serem escutados e não só para serem lidos, e os únicos bons são aqueles que comovem. ${ }^{44}$ Conformar-se com estas novas regras não significa, para Tocqueville, deixar-se levar pela demagogia: não é, de forma alguma, uma questão de se rebaixar à raia destes candidatos ambulantes, que disseminavam, de palanque em palanque, seus protestos. ${ }^{45}$ Não, Tocqueville não aceita se submeter senão ao sufrágio daqueles a quem percebia como sua gente, ou mesmo seus devedores: os eleitores de sua circunscrição.

Mas, sem dúvida, é na análise dos acontecimentos que Tocqueville traiu mais claramente a dificuldade que sentia de se subtrair às próprias emoções. O bom observador político é aquele que pode antecipar os acontecimentos que virão, recorrendo não somente à análise racional dos fatos que conhece, mas se apoiando também na intuição: Tocqueville não esconde um certo orgulho ao afirmar que, mesmo não tendo previsto a revolução em toda sua amplitude, havia sentido sua chegada. E o faz do mesmo modo com que ostenta suas antipatias e ódios, para, na verdade, se consternar: mau guia, em política, eu reconheço, é o sentimento particular que os homens nos inspiram. ${ }^{46}$ No entanto, este mau guia cumpriu, com muita freqüência, seu ofício. Pode-se vê-lo agir, quando se trata de avaliar a conduta dos homens a quem Tocqueville retrata. É também fácil de adivinhar sua presença nas breves confidências de Tocqueville, de onde emanam ódio e desprezo. Assim, chega-se, por exemplo, a esta brutal rememoração: naquele momento, tínhamos, como porteiro da casa que habitávamos na Rue de la Madaleine, um homem extremamente mal afamado no bairro, um antigo soldado, um pouco maluco, beberrão, e muito folgazão, que passava todo o tempo no cabaré, que não se importava de bater em sua mulher. Pode-se dizer que tal homem era socialista de nascimento, ou antes, de temperamento. ${ }^{47} \mathrm{Em}$ Tocqueville, longe do ideal de uma política desencantada, tudo leva a crer que ele vê as coisas ao contrário do seu modo habitual. Este é o sonho inacabado de um liberalismo cultural, que, talvez, ainda hoje não teria dito sua última palavra.

Pode-se dizer ainda: advogar a favor de uma história das emoções políticas não é nem defender a idéia da autonomia dos atores, nem crer que o emocional constitua o vínculo político, em detrimento de todo o cognitivo. Trata-se somente de ampliar o escopo das indagações, de 
explorar uma massa de dados que determinados analistas da política já começaram a explorar. Esse é um dos interesses que se pode atribuir à leitura feita, por Tocqueville, dos eventos de 1848. Por detrás do exame do papel das emoções na vida política, trata-se também de retornar às questões clássicas da história política da França contemporânea. A primeira se atém aos patamares de politização: o vínculo político não é um dado estável da história política da França contemporânea. Desde a Revolução Francesa, de forma desigual segundo os territórios e os grupos a que diz respeito, a politização conheceu formas e intensidades variadas, sendo perpetuamente redistribuídas. As fases de altos patamares de politização correspondem a momentos de fortes cargas emocionais: a política invadiu, então, todo o privado, transbordando das instituições que habitualmente a abrigam; perdendo o caráter pacífico de um simples governo das coisas. A segunda grande questão que se abre com a investigação sobre as emoções políticas é da representação. Dizse que se a República está progressivamente tentando encontrar fórmulas para representar os interesses, e que está sempre colidindo com os sentimentos e estilos de vida. Esta última questão não é superficial, e contém, em seu seio, toda uma reflexão sobre a profissão do homem de política, e a relação que mantém com seus mandantes. 